\title{
ICAM-1, E-selectin, and TNF $\alpha$ expression in labial salivary glands of patients with rheumatoid vasculitis
} René Marc Flipo, Thierry Cardon, Marie Christine Copin, Marie Vandecandelaere,
Bernard Duquesnoy, Anne Janin inflammatory injury. ${ }^{6}$ Cellular adhesion molecules and TNF $\alpha$ have been implicated in the pathogenesis of rheumatoid arthritis, ${ }^{67}$ and adhesion molecules might play a role in the pathogenesis of vasculitis by enhancing lymphocyte-endothelial cell molecular interactions and promoting damage to the endothelium. ${ }^{8}$

To determine whether areas with microvascular damage in labial salivary glands from patients with rheumatoid vasculitis show upregulation of cell adhesion molecules and TNF $\alpha$, we have examined the expression of intercellular adhesion molecule 1 (ICAM1), vascular cell adhesion molecule 1 (VCAM1), endothelial leucocyte adhesion molecule-1 (E-selectin), CD44, and TNF $\alpha$ in labial salivary gland biopsy specimen from patients with rheumatoid vasculitis before and after successful treatment. ment.

Conclusions-The expression of ICAM1, E-selectin, and TNF $\alpha$ allows an assessment of the activity of the vasculitic process in rheumatoid vasculitis. Labial salivary gland biopsy findings in patients with rheumatoid arthritis and visceral vasculitis without purpura or neuropathy (that is, mesenteric, coronary, or cerebral vasculitis) would be of interest and are examples where labial salivary gland tissue is more accessible than the affected tissue.

(Ann Rheum Dis 1997;56:41-44)

Diagnosis of rheumatoid vasculitis is sometimes difficult because of the its polymorphic clinical presentation and the difficulties in interpreting the histological findings. ${ }^{1}$ Rheumatoid vasculitis is commonly described as a panarteritis involving blood vessels of all sizes, particularly small arteries such as the digital arteries. ${ }^{2}$ Various tissues have been biopsied to look for pathological evidence of vasculitis in patients with rheumatoid arthritis. ${ }^{34}$ In a previous study, we found pathological features of perivascular inflammatory infiltrate with microvascular damage in labial salivary gland tissue in $90 \%$ of patients with rheumatoid vasculitis compared with only $20 \%$ in a control group of rheumatoid arthritis patients. ${ }^{5}$

There is increasing evidence for the importance of endothelial and leucocyte adhesion molecules in the development of

\section{Methods}

Patients were consecutively recruited in a one year prospective study from one department of rheumatology (table 1). Patients with rheumatoid arthritis fulfilled the criteria proposed by the American Rheumatism Association. ${ }^{9}$ Six groups were formed. Group I was composed of six patients with proven evidence of rheumatoid vasculitis, based on the criteria proposed in 1984 by Scott and Bacon. ${ }^{10}$ Clinical data on these six patients are summarised in table 2. Group II was composed of the same six patients reviewed after a mean period of nine months after treatment (all the patients with rheumatoid vasculitis were treated with intermittent pulses of intravenous cyclophosphamide plus methylprednisolone).$^{10} \mathrm{~A}$ favourable clinical outcome was observed for all these patients. With a mean follow up of one year, none of the patients died. Group III comprised six patients with rheumatoid arthritis without clinical evidence of vasculitis, matched for age and gender. These patients were admitted to hospital because of progressive disease and the need to adjust treatment. Group IV comprised 10 patients with primary Sjögren syndrome without clinical signs of vasculitis or cryoglobulinaemia. Group V comprised 10 patients with rheumatoid arthritis without signs of rheumatoid vasculitis and with proven secondary Sjögren syndrome, defined according to 
Table 1 Clinical and biological features of patients included in the study

\begin{tabular}{|c|c|c|c|c|c|}
\hline Group & $I(n=6)$ & $I I(n=6)$ & $I I I(n=6)$ & $I V(n=10)$ & $V(n=10)$ \\
\hline Male/female & $3 / 3$ & $3 / 3$ & $3 / 3$ & $1 / 9$ & $0 / 10$ \\
\hline Mean age (years) & 57 & 57 & 57 & 56 & 61 \\
\hline $\begin{array}{l}\text { Presence of rheumatoid } \\
\text { nodules }\end{array}$ & 2 & 2 & 1 & 0 & 1 \\
\hline ESR, median (range) & 88 (32 to 140$)$ & $62(22$ to 80$)$ & $53(18$ to 86$)$ & - & - \\
\hline CRP, median (range) & 73 (32 to 133 ) & $31(6$ to 61$)$ & 30 (10 to 7$)$ & - & - \\
\hline $\begin{array}{l}\text { Positive rheumatoid factor } \\
\text { IgM }\end{array}$ & 6 & 6 & 5 & 4 & 8 \\
\hline
\end{tabular}

ESR, erythrocyte sedimentation rate ( $\mathrm{mm}$ in 1 st hour); CRP, C reactive protein ( $\mathrm{mg}$ litre ${ }^{-1}$ )

Table 2 Clinical features of patients with rheumatoid vasculitis

\begin{tabular}{|c|c|c|c|c|c|c|}
\hline Patient & Weight loss & Cutaneous signs & Neurological signs & Other symptoms & Second line drug ${ }^{\star}$ & Corticosteroids \\
\hline 1 & + & $\begin{array}{l}\text { Palpable purpura, } \\
\text { Non-healing leg } \\
\text { ulcers }\end{array}$ & $\begin{array}{l}\text { Peripheral } \\
\text { neuropathy }\end{array}$ & SICCA syndrome & Parenteral gold & + \\
\hline 2 & + & Palpable purpura & $\begin{array}{l}\text { Mononeuritis } \\
\text { multiplex }\end{array}$ & - & - & + \\
\hline 3 & + & $\begin{array}{l}\text { Livedo, purpura, } \\
\text { non-healing leg } \\
\text { ulcers }\end{array}$ & $\begin{array}{l}\text { Mononeuritis } \\
\text { multiplex }\end{array}$ & - & Parenteral gold & + \\
\hline 4 & + & $\begin{array}{l}\text { Palpable purpura, } \\
\text { Non-healing leg } \\
\text { ulcers }\end{array}$ & $\begin{array}{l}\text { Peripheral } \\
\text { neuropathy }\end{array}$ & - & Methotrexate & + \\
\hline 5 & + & - & $\begin{array}{l}\text { Mononeuritis } \\
\text { multiplex }\end{array}$ & - & - & + \\
\hline 6 & - & Extensive leg ulcers & $\begin{array}{l}\text { Mononeuritis } \\
\text { multiplex }\end{array}$ & $\begin{array}{l}\text { Myocardial } \\
\text { infarction }\end{array}$ & Methotrexate & + \\
\hline
\end{tabular}

*At the time of occurrence of clinical signs of rheumatoid vasculitis

Table 3 Pathological results

\begin{tabular}{|c|c|c|c|c|c|c|}
\hline & Group I RV & $\begin{array}{l}\text { Group II RV } \\
\text { after treatment }\end{array}$ & Group III RA & Group IV pSS & Group VsSS & $\begin{array}{l}\text { Group VI } \\
\text { Control group }\end{array}$ \\
\hline Number of patients & 6 & 6 & 6 & 10 & 10 & 6 \\
\hline $\begin{array}{l}\text { Intravascular fibrin } \\
\text { deposits }\end{array}$ & 6 & 1 & 0 & 0 & 0 & 0 \\
\hline Vascular wall oedema & 6 & 2 & 1 & 1 & 1 & 1 \\
\hline \multicolumn{7}{|l|}{ Lymphocytic infiltrate - } \\
\hline Focus score $<1 \dagger$ & 4 & 5 & 4 & 0 & 0 & 5 \\
\hline Focus score $\geq 1$ & 2 & 1 & 2 & 10 & 10 & 1 \\
\hline Neutrophilic infiltrate & 4 & 1 & 0 & 0 & 0 & 0 \\
\hline Eosinophilic infiltrate & 0 & 1 & 0 & 0 & 0 & 0 \\
\hline Mast cell infiltrate & 2 & 1 & 1 & 1 & 1 & 1 \\
\hline Vascular wall necrosis & 1 & 0 & 0 & 0 & 0 & 0 \\
\hline
\end{tabular}

RV, rheumatoid vasculitis; RA, rheumatoid arthritis; pSS, primary Sjögren syndrome; sSS, secondary Sjögren syndrome †Chisholm's focus score ${ }^{12}:$ a focus is an aggregate of more than 50 round cells on $4 \mathrm{~mm}^{2}$.

the criteria proposed in 1993 by the European Spondylarthropathy Study Group. ${ }^{11}$ Group VI (control group) was composed of six appropriately aged patients suffering from chronic low back pain or sciatica. Their informed consent was obtained.

\section{PATHOLOGICAL STUDY}

All patients underwent labial salivary gland biopsy under local anaesthesia ( $1 \%$ xylocaine hydrochloride with $1 / 8000$ adrenaline) with their informed consent. Three minor salivary glands were excised from the lower labial mucosa. The incision was minimal, selectively performed over the salivary duct aperture in the mouth, and no suture was required.

The salivary glands were immediately fixed in $4 \%$ paraformaldehyde and further processed for paraffin embedding. Serial sections were made from the paraffin blocks. Haematoxylineosin and May-Grünwald-Giemsa stains were performed. Sections were analysed to evaluate the infiltrate according to Chisholm's focus score (a focus is an aggregate of more than 50 round cells on $4 \mathrm{~mm}^{2}$ ), ${ }^{12}$ and to assess the microvascular damage: thrombosis, intravascu- lar fibrin deposits, vascular wall oedema, and polymorphonuclear and/or lymphocytic infiltrate.

IMMUNOHISTOLOGICAL STUDY

An indirect immunoperoxidase method was performed, using the following murine monoclonal antibody reagents of the $\mathrm{IgG} 1$ subclass, produced by Immunotech SA: 84H10 (anti-ICAM1), 1G11 (anti-VCAM1), 1.2B6 (anti-E-selectin), and J-173 (antiCD44, standard form). A polyclonal antibody produced by Genzyme recognised TNF $\alpha$. The ABComplex/AP (Dakopatts) was used as staining procedure. Controls included: (1) omission of the first antibody, (2) positive controls on endothelial cell culture for ICAM1, VCAM1, and E-selectin, on rheumatoid arthritis synovial tissue for CD44, and on skin with acute graft-versus-host lesions for TNF $\alpha$.

The slides were analysed blindly by two different pathologists.

Statistical analysis was performed using non-parametric tests (Wilcoxon). 
Table 4 Number of patients expressing ICAM1, VCAM1, E selectin, and TNF $\alpha$ in rheumatoid vasculitis before treatment (bold numbers) (group I) and after treatment (group II) $(n=6)$

\begin{tabular}{llllll}
\hline & ICAM1 & VCAM1 & E-selectin & CD44 & TNF a \\
\hline $\begin{array}{l}\text { Areas of microvascular } \\
\text { damage }\end{array}$ & & & & & \\
$\begin{array}{l}\text { Endothelium } \\
\text { Cellular infiltrate }\end{array}$ & $\mathbf{5}-0$ & $\mathbf{2}-0$ & $\mathbf{5}-0$ & $\mathbf{3}-0$ & $\mathbf{6}-0$ \\
$\begin{array}{l}\text { Areas devoid of } \\
\text { microvascular damage }\end{array}$ & $\mathbf{5}$ & $\mathbf{0}-0$ & $\mathbf{0}-0$ & $\mathbf{3}-0$ & $\mathbf{6}-0$ \\
$\begin{array}{l}\text { Endothelium } \\
\text { Lymphocytes }\end{array}$ & $\mathbf{2}-0$ & $\mathbf{0}-0$ & $\mathbf{1}-0$ & $\mathbf{3}-0$ & $\mathbf{2}-0$ \\
Duct epithelial cells & $\mathbf{0}-0$ & $\mathbf{0}-0$ & $\mathbf{0}-0$ & $\mathbf{0}-0$ & $\mathbf{1}-0$ \\
& $\mathbf{5}-0$ & $\mathbf{0}-0$ & $\mathbf{0}-0$ & $\mathbf{4}-0$ & $\mathbf{5}-0$ \\
\hline
\end{tabular}

\section{Results}

Table 3 summarises the pathological signs of microvascular damage observed on labial salivary gland biopsies. Microvascular damage was found in all patients of group I. In the biopsies taken at the time of the diagnosis of rheumatoid vasculitis, we detected an intense perivascular inflammatory infiltrate which was mainly composed of macrophages and lymphocytes, with some neutrophils. After treatment, these pathological features were only present in two cases. A perivascular

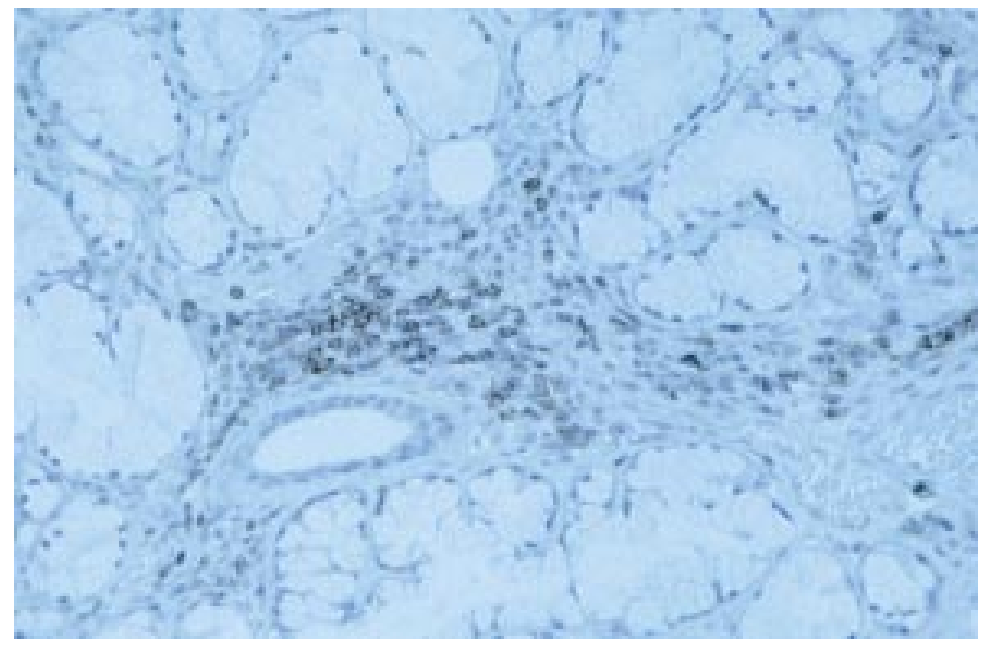

Figure 1 Labial salivary gland from a patient with rheumatoid vasculitis (patient 4): intense staining with an antibody directed against TNF $\alpha$ in a zone with a dense perivascular infiltrate (arrow = capillary). Indirect immunoperoxidase $\times 310$.

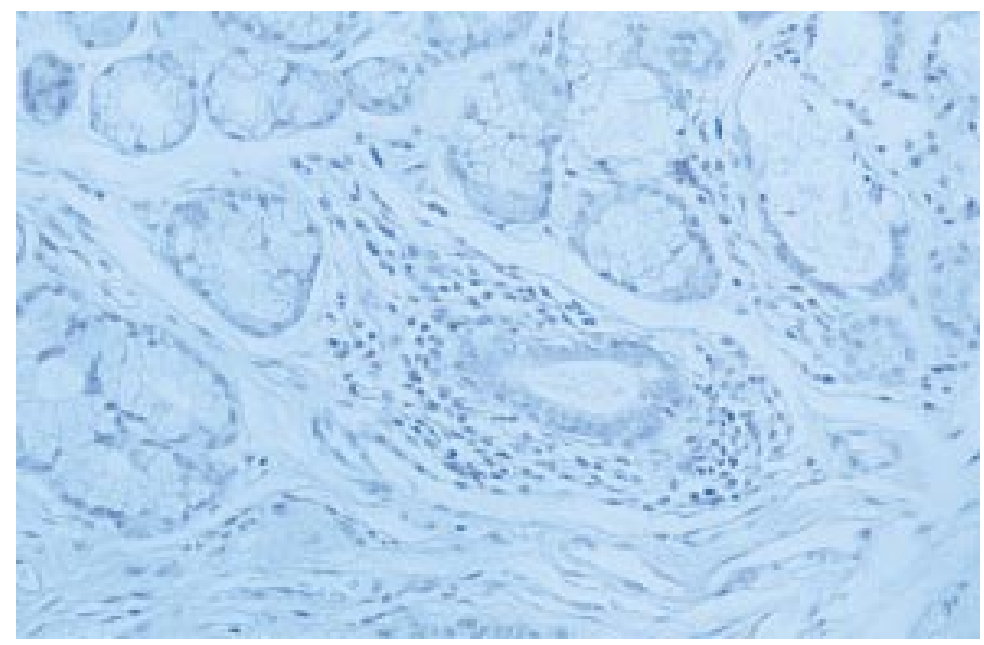

Figure 2 Same patient as in fig 1 in clinical remission after treatment. The dense inflammatory infiltrate is still present but there is no staining with the antibody directed against TNF a. Indirect immunoperoxidase $\times 310$. infiltrate was found in only one patient of group III and one of the group VI. No patient with Sjögren syndrome (group IV and group V) had pathological evidence of microvascular damage.

The distribution of cell adhesion molecules and TNF $\alpha$ in the patients of group I and II is summarised in table 4. Cell adhesion molecules were expressed in areas of microvascular damage in group I. TNF $\alpha$, ICAM1, and E-selectin, but not VCAM1 and CD44, were significantly expressed in group $I$ in comparison with all the other groups $(\mathrm{P}<$ 0.05). TNF $\alpha$ (fig 1) was strongly expressed in endothelial and mononuclear cells in areas of microvascular damage.

In areas devoid of microvascular damage, the expression of adhesion molecules was limited to endothelial and duct epithelial cells. In group I patients, the duct epithelium close to inflammatory foci was marked by antibodies directed against ICAM1, CD44, and TNF $\alpha$.

No staining was seen in group III (rheumatoid arthritis) and VI (control). In group IV (primary Sjögren syndrome), only one patient had positive immunostaining for ICAM1 on endothelial cells. In group V (secondary Sjögren syndrome), one patient had ICAM1 staining on endothelial cells, and only one other patient had TNF $\alpha$ staining on mononuclear infiltrate. It is interesting to note that the two patients without clinical signs of vasculitis but with features of microvascular damage on haematoxylin-eosin sections had absolutely no staining on the following sections treated with antibodies directed against adhesion molecules and TNF $\alpha$ (fig 2). Follow up of these two patients over a period of two years confirmed the absence of progressive vasculitis.

\section{Discussion}

Rheumatoid vasculitis is an uncommon but extremely severe complication of rheumatoid arthritis. Systemic rheumatoid vasculitis shares similarities with polyarteritis nodosa and may require equally aggressive treatment. ${ }^{10}$ The wide spectrum of cutaneous and systemic signs and symptoms manifested in vasculitis can account for the difficulties in the diagnosis. Moreover, it can be impossible to biopsy injured tissues. We performed this systematic assessment of rheumatoid vasculitis after an initial study ${ }^{5}$ in which we stressed the value of labial salivary gland biopsy in diagnosing rheumatoid vasculitis, particularly in the absence of other accessible lesions. Labial salivary gland biopsy is easy to perform under local anaesthesia and appears to be a relative minor and safe procedure. The presence of microvascular damage in salivary gland tissue in patients with rheumatoid vasculitis may reflect the dissemination of this vascular inflammatory process.

Only one patient had histological features of necrosis. This is not surprising since necrotic vasculitis is only visible in the most advanced stages of rheumatoid vasculitis. Immune deposits are inconsistent and non-specific. ${ }^{13}$ Models of vasculitic processes exist where 
microvascular damage occurs in the absence of immune complex deposition. ${ }^{14}$ In a recent report, the role of $\mathrm{CD} 1 \mathrm{~b} / \mathrm{CD} 18-\mathrm{ICAM} 1$ expression on circulating leucocytes has been demonstrated in such a cytokine primed rabbit model of vasculitis. ${ }^{14}$

Since ICAM $1,{ }^{15}$ VCAM1, ${ }^{16}$ E-selectin, ${ }^{17}$ CD $44,{ }^{18}$ and TNF $\alpha^{715}$ are involved in the pathological process of rheumatoid arthritis, we systematically studied the expression of these proteins in labial salivary gland tissue in rheumatoid vasculitis. Analysis of the results showed that ICAM1, E-selectin, and TNF $\alpha$ were significantly expressed in labial salivary gland tissue of patients with evolving rheumatoid vasculitis. These results may have implications in the pathogenesis of rheumatoid vasculitis. Our study suggests a role for ICAM1, E-selectin, and TNF $\alpha$ in the vasculitic lesions in rheumatoid vasculitis but it does not exclude participation of antigenantibody complexes, as in immune complex induced lung vascular injury. ${ }^{19}$ Moreover, VCAM1 expression is rare in labial salivary gland tissue of group I patients. The expression of VCAM1 is increased by interleukin 4 , the main cytokine secreted by TH2 lymphocyte. ${ }^{20}$ This might imply that most perivascular lymphocytes in rheumatoid vasculitis are of the TH1 rather than the TH2 type. The lack of associated eosinophils in the perivascular infiltrate of rheumatoid vasculitis patients is in favour of this hypothesis.

In the present study, positive immunostaining for the three adhesion molecules or TNF $\alpha$ was only seen in patients with clinical evidence of rheumatoid vasculitis. Moreover immunohistological studies of ICAM1, E-selectin, and TNF $\alpha$ allowed the distinction between progressive and non-progressive rheumatoid vasculitis in patients where the clinical signs were inconsistent with the pathological data. The tissue expression of these proteins may thus be used to assess the activity of the vasculitic process. The absence of staining in groups IV and V illustrates the specificity of TNF $\alpha$ and adhesion molecules staining in active rheumatoid vasculitis, independently of the possible combination of rheumatoid arthritis with Sjögren syndrome. Moreover, previous studies had shown the absence or low expression of ICAM 1, ELAM $1,{ }^{21}$ and CD 44 in primary Sjögren syndrome. ${ }^{22}$

Treatment for rheumatoid vasculitis resulted in a favourable clinical outcome in all patients. When a second biopsy was performed, immunostaining for the three adhesion molecules orTNF $\alpha$ was negative, even in areas of persisting microvascular damage. The high doses of corticosteroids or cyclophosphamide might have inhibited the expression of these proteins. ${ }^{15}{ }^{23}$ However, the value of ICAM1, E-selectin, and TNF $\alpha$ expression in the assessment of the therapeutic response in rheumatoid vasculitis has to be studied further.

\section{CONCLUSION}

The expression of ICAM1, E-selectin, and TNF $\alpha$ allows an assessment of the activity of the vasculitic process in rheumatoid vasculitis.
Labial salivary gland biopsy findings in patients with rheumatoid arthritis and visceral vasculitis without purpura or neuropathy (that is, mesenteric, coronary, or cerebral vasculitis) would be of interest and are examples where labial salivary gland tissue is more accessible than the affected tissue.

1 Grishman E, Spiera H. Vasculitis in connective tissue diseases, including hypocomplementemic vasculitis. In: Churg A, Churg J, eds. Systemic vasculitis. New York: Raven Press, 1991:273-92.

2 Vollertsen RS, Conn DL, Ballard DJ, Ilstrup DM, Kazmar RE, Silverfield JC. Rheumatoid vasculitis: survival and associated risk factors. Medicine 1986;65:365-75.

3 Tribe CR, Scott DGI, Bacon PA. Rectal biopsy in the diagnosis of systemic vasculitis. J Clin Pathol 1981;34:843-50.

4 Krauss A, Palacio SA, Munoz L. Muscular involvement in systemic rheumatoid vasculitis. Br J Rheumatol 1992;31:355-8.

5 Flipo RM, Janin A, Hachulla E, Houvenagel E, Foulet A, Cardon T, et al. Labial salivary gland biopsy in rheumatoid vasculitis. Ann Rheum Dis 1994;53:648-52.

6 Cronstein BN, Weissmann G. The adhesion molecules of inflammation. Arthritis Rheum 1993;36:147-57.

7 Brennan FM, Maini RN, Feldman M. TNF $\alpha-$ a pivotal role in rheumatoid arthritis? $\mathrm{Br} \mathrm{J}$ Rheumatol 1992; 31:293-8.

8 Ginsberg MH. Cell adhesion receptors and vasculitis. In: Carwile Le Roy E, ed. Systemic vasculitis: the biological basis. New York: Marcel Decker, 1992:505-24.

9 Arnett FC, Edworthy SM, Bloch DA, McShane DJ, Fries JF, Cooper NS, et al. The American Rheumatism Association 1987 revised criteria for classification of rheumatoid arthritis. Arthritis Rheum 1988;31:315-24.

10 Scott DGI, Bacon PA. Intravenous cyclophosphamide plus methylprednisolone in treatment of systemic rheumatoid vasculitis. Am J Med 1984;76:377-84.

11 Vitali C, Bombardieri S, Moutsopoulos HM, Balestrieri G, Bencivelli W, Bernstein RM, et al. Preliminary criteria for the classification of Sjögren's syndrome. Results of a prospective concerted action supported by the European Community. Arthritis Rheum 1993;36:340-7.

12 Chisholm DM, Mason DK. Labial salivary gland biopsy in Sjögren's disease. J Clin Pathol 1968;21:656-60.

13 McGill PE, Brougham PA, Tulloch J. Immune deposits in the skin of patients with rheumatoid arthritis. J Rheumatol 1984;11:454-6.

14 Argenbright LW, Barton RW. Interactions of leukocyte integrins with intercellular adhesion molecule 1 in the production of inflammatory vascular injury in vivo. J Clin Invest 1992;89:259-72.

15 Tessier P, Audette M, Cattaruzi P, McColl SR. Upregulation by tumor necrosis factor $\alpha$ of intercellular adhesion molecule 1 expression and function in synovial fibroblasts and its inhibition by glucocorticoids. Arthritis Rheum 1993;36:1528-39.

16 Marlor CW, Webb DL, Bombara MP, Greve JM, Blue M. Expression of vascular cell adhesion molecule-1 in fibroblast synoviocytes after stimulation with tumor necrosis factor. Am J Pathol 1992;140:1055-9.

17 Postigo AA, Garcia-Vicuna R, Diaz-Gonzalez F, Arroyo AG, De Landazuri MO, Chi Rosso G, et al. Increased binding of synovial $\mathrm{T}$ lymphocytes from rheumatoid arthritis to endothelial-leukocyte adhesion molecule-1 (ELAM-1) and vascular cell adhesion molecule-1 (VCAM-1). J Clin Invest 1992;89:1445-52.

18 Haynes BF, Hale LP, Patton KL, Martin ME, McCallum RM. Measurement of an adhesion molecule as an indicator of inflammatory disease activity. Up-regulation of the receptor for hyaluronate (CD44) in rheumatoid arthritis. Arthritis Rheum 1991;34:1434-43.

19 Mulligan MS, Wilson GP, Todd RF. Role of $\beta 1 \beta 2$ integrins and ICAM-1 in lung injury after deposition of IgG and IgA immune complexes. J Immunol 1993;150:2407-17.

20 Romagnani S. Induction of $\mathrm{TH} 1$ and $\mathrm{TH} 2$ responses: a key role for the natural immune response? Immunol Today 1992;13:379-81.

21 Saito I, Tsubota K, Takeuchi T, Miyasaka N. VLA-4/ VCAM-1 pathway in the salivary and lacrimal glands of Sjögren's syndrome. Arthritis Rheum 1992;35:S231.

22 St Clair EW, Angellilo JC, Singer KH. Expression of cell-adhesion molecules in the salivary gland microenvironment of Sjögren's syndrome. Arthritis Rheum 1982;35:62-6.

23 Cronstein BN, Kimmel SC, Levin RI, Martiniuk F. A mechanism for the anti-inflammatory effects of corticosteroids: the glucocorticoid receptor regulates leukocyte adhesion to endothelial cells and expression of adhespression of lar adhesion molecule 1. Proc Natl Acad Sci USA 1992;89:9991-5. 